\title{
Are wintering Common Redpolls Carduelis flammea more exposed to avian predators than other small passerines?
}

\section{Olav Hogstad}

Norwegian University of Science and Technology, NTNU University Museum, NO-7491 Trondheim, Norway; e-mail: Olav.Hogstad@ntnu.no

\begin{abstract}
The Common Redpoll Carduelis flammea is a highly social flocking bird which forms cohesive groups outside the breeding season. Being small birds $(12-15 \mathrm{~g})$, they need to forage almost continuously during a few hours of daylight in winter to meet their energy demands. Although predation risk is reduced as a result of improved surveillance of many eyes, increased flock size may also increase the agonistic interactions among individuals within the flock and as a consequence lower the probability of detection of a predator's approach. To examine whether Common Redpolls, living in relatively large winter flocks, are more exposed to avian predators than small passerines living in groups of only a few individuals, I recorded the responses of Common Redpolls, Willow Tits Poecile montanus and Great Tits Parus major to a life-like stuffed specimen of two different predators, the Siberian Jay Perisoreus infaustus (body length $30 \mathrm{~cm}$ ) and the Hooded Crow Corvus cornix $(50 \mathrm{~cm})$. After the presentation of a predator model, Redpolls returned to the seed sites on the average earlier than the tits, and significantly so versus both tit species after exposure to the Siberian Jay, and for Great Tits after exposure to the Hooded Crow. Whereas Willow and Great Tits seemed to pick up sunflower seeds in the snow without much competition, Common Redpolls displayed a more conspicuous, aggressive, intraspecific behaviour. Thus, the individual vigilance of Common Redpolls was most likely reduced and exposure time to predation increased. The seed-eating Common Redpolls may be more food-stressed than the year-round resident Willow Tits that have stored food within their territories. If so, Common Redpolls may be forced to take greater predation risks because of a higher hunger level. If the differences in return times after exposure to a predator model reflected an adaptation to perceived predation risk, the Common Redpolls apparently evaluated the Siberian Jay as less dangerous than did the tits.
\end{abstract}

Key words: Antipredator responses; Common Redpoll; parids

\section{INTRODUCTION}

Winter survival depends on foraging efficiency and predator avoidance (DeLaet 1985, Rands 2017). Periods with low temperatures demand greater foraging effort, and time allocation to food seeking may reduce time to vigilance behaviour. Because of energy stress during cold periods, birds are forced to increase their time for foraging and therefore also increase the probability of being predated. However, survival benefits may be gained by participating in flocks because predation risk is reduced as a result of improved surveillance by many eyes (Pulliam 1973). On the other hand, increased flock size may also increase aggression due to competition for food (Hogstad 1988) and so reduce the level of surveillance, which in turn may increase the risk of predation.

During my studies on wintering small passerines in a forest in Budal, central Norway, I have seen Common Redpolls Carduelis flammea (from here Redpolls) being attacked by Hawk Owls Surnia ulula and Eurasian Magpies Pica pica (Hogstad 1986, 1996), and also a Siberian Jay Perisoreus infaustus that made unsuccessful attacks on Redpolls foraging on seeds in the snow. Furthermore, I sometimes found blood together with down and body feathers from Redpolls in the snow beneath feeders provided with seeds. Although different passerines such as parids and finches frequently visited the feeders, I never found feathers indicating that other species than Redpolls had been killed. It may therefore be suggested that Redpolls are more exposed to predators than other small passerines.

Redpolls are highly social flocking birds which forms cohesive groups outside the breeding season. They breed regularly in the mountain heath birch forest (altitude 750-900 m) about $20 \mathrm{~km}$ from my study area in Budal, and are frequently seen in the Budal forest (mixed forest of Scots pine and downy birch, altitude $600-650 \mathrm{~m})$ outside the breeding season. The yearly population density of redpolls varies considerably (Hogstad 1996), and especially in the winters of 2014 and 2015 many flocks moved around in the area.

To examine whether Redpolls, living in relatively large winter flocks, are more exposed to avian predators than small passerines living in groups of few individuals, I compared the response of Redpolls with that of Willow Tits Poecile montanus and Great Tits Parus major to a life-like stuffed specimen of 
two different predators, the Siberian Jay Perisoreus infaustus (occurring in the Budal forest, but not in the heath birch forest) and the Hooded Crow Corvus cornix (occurring in both forests). After 5 minutes of presentation, the model was removed and I recorded the birds' sequences of return to the feeding site and their behaviour. Differences in the return time among the small passerines after exposure to the predator dummy were hypothesized to indicate their perceptions of the level of threat.

\section{MATERIAL AND METHODS}

The field work took place in January-March in 2013 -2017 in Budal, $90 \mathrm{~km}$ south of Trondheim, in central Norway (ca. $\left.63^{\circ} \mathrm{N}\right)$. The wintery weather most often sets in about mid-October. At this latitude, the daylight period is short in midwinter (21 December: 4 hrs. 31 min.). The potential avian predators of small passerines in the area are Hawk Owl, Sparrowhawk Accipiter nisus, Great Grey Shrike Lanius excubitor and the corvids Hooded Crow, Siberian Jay and Eurasian Magpie.

Several feeders were placed in the area, most of them being stationary and situated more than $400 \mathrm{~m}$ from each other. The feeders were regularly provided with some sunflower seeds in autumn and winter. Although the feeders could be empty for several days, they were regularly visited by resident Willow Tits. Each experiment started when redpolls and tits were present. Sunflower seeds were then spread on the snow beneath a feeder 5-10 minutes before the stuffed model was mounted. As the seeds were spread within an area of about one metre in diameter, the birds most often had to compete for the food.

The predator model was mounted on a branch about $2 \mathrm{~m}$ above the ground and about $2 \mathrm{~m}$ from the seed site and facing the site. The birds were observed (from a hide placed $10-15 \mathrm{~m}$ from the feeder) for two periods: one during 5 minutes after the predator model had been mounted, and one after removal of the model, when I noted their sequences of return to the feeding site. After presenting a model, the trial was repeated about 3-4 hours later with the second model at the same feeder. The model presentations were done in random order and on the same day. I cannot exclude that the first presentation did influence the results of the second trial. However, by showing the predator models, at the most only once a week at each trial site, the risk of the birds habituating to the stuffed predator was minimized. A high proportion (annually 30-60\%) of the Willow Tits were colour-ringed. Because of the long distance between the trial sites, I never observed that any of the ringed adult Willow Tits visited more than one of the specific sites. I therefore consider the data to be of individual tits from different flocks and thus have avoided the risk of pseudoreplications.

In total 50 series (23 with Siberian Jay, 27 with Hooded Crow) were performed when Redpolls and Willow Tits were at the site at the same time, of which 20 included Redpolls, Willow and Great Tits. Several trials failed because none of the birds (Redpolls or tits) returned to the site within 15 minutes after presentation of a model. Based on plumage characters, distinction was made between adult males and females or firstyear Redpolls (Svensson 1992).

The tests are two-tailed, and were performed using SPSS 23. Data were analysed using nonparametric statistical tests and significance was accepted at $\mathrm{p} \leq$ 0.05 .

\section{RESULTS}

Willow Tits regularly checked the feeder sites and were always the first to arrive after I had put sunflower seeds in the feeder and spread seeds on the snow beneath it. These tits were members of one of the several permanent winter flocks that moved around within their territories, occasionally in company with Great Tits. The flocks that most often visited the feeders consisted of 3-6 Willow Tits, 1-3 Great Tits and 6 to ca 20 Redpolls. Although some feeders were visited by Blue Tits Cyanistes caeruleus and finches, these birds did not influence the data because they usually entered the sites relatively late in the experiment procedures.

The foraging and storing activity of the Willow Tits probably serve as signals to Redpolls and other birds seeking for food. Since the year-round resident Willow Tits probably have good knowledge of the local food distribution, Redpolls, moving around in the area, may be attracted to the feeding sites by acoustic utterings by the tits.

During the 5-minute period when a stuffed model was mounted, the birds moved restlessly around or hovered in the air while giving alarm calls. None was observed picking sunflower seeds in the snow. After the stuffed Siberian Jay was removed, Redpolls were the first to return in 20 of 23 cases, but as the first in only 15 of 27 after the Hooded Crow was removed (Table 1). Thus, Redpolls returned faster after the removal of the jay than after the crow (Mann-Whitney U-test: $\mathrm{Z}=2.51, \mathrm{p}=0.01)$. After the jay removal, Redpolls $($ median $=1)$ returned before Willow Tits (median $=$ $2 ; \mathrm{Z}=5.21, \mathrm{p}<0.001$ and Great Tits (median $=2, \mathrm{Z}=$ $\left.4.57, \mathrm{n}_{1}=23, \mathrm{n}_{2}=11, \mathrm{p}<0.001\right)$, while there were no differences in return time between Willow and Great Tits $(Z=1.58$, n.s. $)$.

Willow Tits returned on average significantly later to the feeder (median $=2$ ) after the jay than after the crow presentation (median $=1 ; \mathrm{Z}=2.72, \mathrm{P}<0.01$ ). However, there were no such differences for Great Tits $\left(\mathrm{Z}=0.0, \mathrm{n}_{1}=11, \mathrm{n}_{2}=9, \mathrm{~ns}\right)$. Accordingly, given that 
Table 1. The sequence of return by Redpolls, Willow and Great Tits to a feeding site with sunflower seeds after a life-like stuffed model of Siberian Jay or Hooded Crow had been mounted about $2 \mathrm{~m}$ from the site for 5 minutes and then removed.

\begin{tabular}{|c|c|c|c|c|c|c|c|c|}
\hline & \multicolumn{4}{|c|}{ Siberian Jay } & \multicolumn{4}{|c|}{ Hooded Crow } \\
\hline & \multicolumn{3}{|c|}{ Sequence of return } & \multirow{2}{*}{$\begin{array}{c}\text { Number of } \\
\text { trials }\end{array}$} & \multicolumn{3}{|c|}{ Sequence of return } & \multirow{2}{*}{$\begin{array}{c}\text { Number of } \\
\text { trials }\end{array}$} \\
\hline & 1 & 2 & 3 & & 1 & 2 & 3 & \\
\hline Redpoll & 20 & 3 & 0 & 23 & 15 & 8 & 4 & 27 \\
\hline Willow Tit & 2 & 16 & 5 & 23 & 8 & 19 & 0 & 27 \\
\hline Great Tit & 1 & 4 & 6 & 11 & 3 & 0 & 6 & 9 \\
\hline
\end{tabular}

the differences in return times after facing the predator models reflects the potential prey species' perception of the specific predators' element of risk, the Redpolls apparently evaluated the Siberian Jay as less dangerous than the larger sized Hooded Crow, whereas Willow Tits evaluated the predation risk of the Siberian Jay as higher than that of the crow. The Great Tits, however, evaluated the jay $($ median $=3)$ and the crow (median $=$ 3 ) as equally dangerous.

Immediately after the first Redpoll landed in the snow to pick up sunflower seeds, other Redpolls followed. Generally, females or first-year birds were the first to enter the seed sites. Whereas Willow and Great Tits picked up seeds in the snow without much competition, Redpolls displayed an aggressive intraspecific behaviour, and members of the groups were continually interacting with one another. The behaviour patterns used in agonistic interactions were mostly supplanting attacks in which one bird flew at another which retreated and the attacker took its place. However, also physical attacks were frequently observed in which the attacker pecked directly at the body or wings of the other bird. Most of the aggression was initiated by males which dominated females and first-year birds. As contests escalated, it was most likely that the individual vigilance level was reduced whereas their exposure time to predation increased.

\section{DISCUSSION}

After the predator model was removed, each individual had to decide how long to wait to make sure that the predator had left the site before returning. If the predator had still been around, individuals returning first would likely have been at greater risk of being attacked. Redpolls were the first to return to the feeding site in $87 \%$ of the trials after the removal of the Siberian Jay and in $56 \%$ after removal of the Hooded Crow, whereas each of the tit species returned as the first species in only $9 \%$ of the trials after the jay and about $30 \%$ after the crow presentation. The tits apparently waited to resume feeding, and it may be suggested that they used Redpolls to ascertain whether it was dangerous to resume visiting the trial site.

Why should Redpolls take more predation risks than tits? A major factor may be the relative hunger level. Redpolls may be forced to adopt a more risky behaviour to meet their daily intake need. Being a small bird (12-15g), the Redpoll needs to forage for ca 8.5 hours per day at $-22^{\circ} \mathrm{C}$ to achieve necessary energy intake of ca $108 \mathrm{~kJ}$ (Pohl 1989). Because lowest winter temperatures often are between -20 and $-30^{\circ} \mathrm{C}$ in the Budal area, and the daylight period is only $4-5$ hours, the seed-eating redpolls may be more food-stressed than the year-round resident Willow Tits that store food within their territories. Redpolls utilize more of the daytime and forage in less light than other passerines (Brooks 1968, Hogstad unpublished data), and may even utilize moonlight for foraging (Bernhoft-Osa 1978). Redpolls may therefore take greater predator risks than tits, as supported by the present experiment.

Different hunger levels between high and low ranked Redpoll individuals may support this hypothesis. Among the Redpolls, lowest-ranked birds (females or first-year birds) consistently returned before dominant adult males. As found for Willow Tits (Silverin et al. 1984), juvenile Redpolls are presumably more stressed, and their energy budget more strained than that of dominant, older males, causing the former to take greater risks.

Furthermore, Redpolls shift from foraging mostly in trees in summer to ground throughout autumn and winter (Cramp \& Perrins 1994). Therefore, Redpolls, foraging on the snow in winter, apparently expose themselves more to avian predators than passerine birds foraging in trees.

Another, but more speculative explanation to the different patterns of behaviour by Redpolls and Willow Tits, may be different adaptations to their respective local predator regimes in the mixed and the subalpine heath birch forest. The Redpoll, being one of the species of the passerine bird community in subalpine birch forests, is heavily predated by the Hooded Crow that, in addition to being a nest predator, also represents a deadly danger to the adult birds (Hogstad unpublished data). As opposed to Hooded Crows, Siberian Jays do not breed in the heath birch forest, but are year- 
round residents in the Budal mixed forest (Hogstad 2016). It may therefore be speculated if Redpolls, and in particular first-year birds, generally inhabiting the mixed forest only in winter, are less familiar with the fear that the Siberian Jays represent. Also the aggressive intraspecific behaviour of the Redpolls on the seed sites may lead to a decreased vigilance and lower their probability of detection of an approaching predator. Willow Tits, however, have coexisted with Siberian Jays for a longer period, and thus may be more aware of the Siberian Jay as a dangerous predator. In addition, flocks of Willow Tits are smaller, with rank hierarchy established since autumn (Hogstad 1987), causing less competition among the flock members so that more time can be spent on vigilance.

The results from the present study indicate that Redpolls behave less cautiously than tits in winter and increase their potential rate of food intake at the expense of increased predation risk. In addition, the aggressive behaviour of the Redpolls on the seed sites may also lead to decrease in vigilance and increase exposure to predation. Moreover, that Sparrowhawks and small owls (Mikkola 1983, Hogstad 1986) catch their prey by snatching them from the lower branches, or, as Siberian Jays, by hunting on the ground (Hogstad 2016), may also increase the difference in the predatory exposure between the ground foraging Redpolls and tits that forage more in trees. However, Redpolls form larger flocks in winter than tits, decreasing the probability that an individual bird is caught - the dilution effect of social living.

Acknowledgements. I am grateful to Thor Harald Ringsby and Tore Slagsvold for valuable comments which greatly improved this manuscript.

\section{REFERENCES}

Bernhoft-Osa, A. 1978. Nattlig aktivitet hos gråsisik, Acanthis flammea. Vår Fuglefauna 1: 93-95. (In Norwegian;
German summary.)

Brooks, W.S. 1968. Comparative adaptations of the Alaskan Redpolls to the arctic environment. Wilson Bulletin 80: 253-280.

Cramp, S. \& Perrins, C.M. (eds.). 1994. The Birds of the Western Palearctic, Vol. 8. Oxford University Press, Oxford.

De Laet, J.F. 1985. Dominance and anti-predator behaviour of Great Tits Parus major: a field study. Ibis 127: 372377.

Hogstad, O. 1986. On the winter food of the Hawk Owl Surnia ulula. Fauna Norv. Ser. C, Cinclus 9: 107-110.

Hogstad, O. 1987. Social rank in winter flocks of Willow Tits Parus montanus. Ibis 129: 1-9.

Hogstad, O. 1988. Advantages of social foraging of Willow Tit Parus montanus. Ibis 130: 275-283.

Hogstad, O. 1996. Population fluctuation of the Redpoll Carduelis flammea during 31 years in a subalpine Birch forest in Central Norway. Vår Fuglefauna 19: 149-155. (In Norwegian; English summary.)

Hogstad, O. 2016. Hunting strategies by Siberian Jays Perisoreus infaustus on wintering small rodents. Ornis Norvegica 39: 25-28.

Mikkola, H. 1983. Owls in Europe. Poyser, Calton.

Pohl, H. 1989. Survival strategies of high-latitude resident Redpolls. Pp. 713-718 in: Mercer, J.B. (ed.). Thermal Physiology. New York.

Pulliam, H.R. 1973. On the advantages of flocking. Journal of Theoretical Biology 38: 419-422.

Rands, S.A. 2017. Leaving safety to visit a feeding site: is it optimal to hesitate while exposed? Royal Society Open Science 4:12 (doi: 10.1098/rsos.160910).

Silverin, B., Viebke, P. \& Westin, J. 1984. Plasma levels of luteinizing hormone and steroid hormones in free-living groups of Willow Tits (Parus montanus). Hormones and Behaviour 18: 367-379.

Svensson, L. 1992. Identification Guide to European Passerines. Privately published, Stockholm.

Received 25 October 2017. Accepted 31 October 2017 